\title{
O Papel das Organizações Não-Governamentais na Conservação da Natureza
}

\author{
Leide Takahashi*
}

Fundação O Boticário de Proteção à Natureza

Em um país que abriga uma das mais ricas biodiversidades do planeta, contribuir para a conservação da natureza deveria ser uma obrigação de todos nós: cidadãos, sociedade civil, empresas e governos. Entretanto, é assustador como esta questão é pouco prioritária em todos os setores da sociedade brasileira.

Não há dúvida que a sociedade civil tem um papel fundamental no desenvolvimento social de qualquer nação. Em busca de ouvidos, atenção e soluções para as questões sociais, as organizações e pessoas, de forma associativa, têm levantado inúmeras bandeiras, buscando apoio efetivo nos setores público e privado. Estes grupos associativos fazem parte do terceiro setor, e desenvolvem de forma espontânea e voluntária iniciativas privadas na esfera pública, que não visam lucro financeiro, em brechas deixadas pelo próprio poder público.

Segundo Fernandes (1994), a definição mais aceita e disseminada de terceiro setor é aquela que preconiza que ele é constituído por organizações sem fins lucrativos e não governamentais, que tem como objetivo gerar serviços de interesse público a partir de recursos privados. O governo é o primeiro setor, responsável pelas ações do Estado com fins e recursos públicos. Representado pelo mercado, o segundo setor é ocupado pelas empresas privadas com fins lucrativos (Rothgiesser 2002; Gonçalves 2002).

Dentre os serviços públicos oferecidos pelas organizações não-governamentais (ONGs), merece destaque a conservação da natureza. Embora em menor número quando comparada às organizações que oferecem serviços de educação e saúde, as ONGs ambientais têm desenvolvido relevantes trabalhos com a finalidade de promover a proteção do patrimônio natural do país. Segundo Djoghlaf (2010), secretário executivo da Convenção sobre Diversidade Biológica $(\mathrm{CDB})$, o mundo permanecerá para sempre em dívida

\footnotetext{
*Send correspondence to: Leide Takahashi Fundação O Boticário de Proteção à Natureza, Rua Gonçalves Dias, 225, Bairro Batel, CEP 80240-340, Curitiba, PR, Brasil

E-mail: leide@fundacaoboticario.org.br
}

com as organizações que atuam em questões ambientais. Elas tiveram uma contribuição fundamental na discussão do tema, na concepção inicial, negociação e aprovação da $\mathrm{CDB}$ e continuam a moldar o desenvolvimento de políticas, além de serem parceiras constantes na implementação da própria Convenção.

Em recente pesquisa desenvolvida pelo Instituto AKATU e que integra o mapeamento mundial Global Survey On Sustainable Lifestyles, realizado pelo Programa das Nações Unidas para o Meio Ambiente (PNUMA), foram entrevistados 1000 indivíduos, com idade entre 18 e 35 anos, de 10 regiões metropolitanas do Brasil. Apesar da ampla divulgação disponível na mídia nos últimos anos, além de ações de mobilização das ONGs, empresas e governo, a questão ambiental foi considerada prioritária para apenas 11\% dos entrevistados (JB Ecológico 2010).

Este resultado chama atenção e merece uma reflexão maior por parte de todos que trabalham ou se interessam pela proteção da natureza, uma vez que os entrevistados de hoje serão líderes num futuro próximo. Se nosso papel, como defensores da biodiversidade, também é influenciar as decisões do governo e os demais setores para que a conservação da natureza seja uma prioridade, fica claro que não estamos sendo convincentes e precisamos buscar maior eficiência.

As organizações não-governamentais que atuam com as questões ambientais precisam se estruturar e profissionalizar cada vez mais. ONGs de pequenos grupos que comungam do mesmo ideal em favor da conservação do patrimônio natural, mas não possuem experiência prática e funcional, não terão muita chance nem credibilidade para se estabelecer de forma diferenciada, diante de tantas instituições que são criadas todos os anos.

No Brasil, segundo Landim (1993), ainda enfrentamos o fato de termos pouca ou quase nenhuma cultura de filantropia, o que pode tornar impossível a implementação de campanhas de captação. Como se não bastasse todas as limitações anteriormente citadas, ainda concorremos em interesse e prioridade com os problemas gerados pelas catástrofes decorrentes do mau uso do solo e da exploração inadequada 
dos demais recursos naturais. É difícil compreender como as pessoas conseguem dissociar os impactos e prejuízos que vários países enfrentaram nos últimos anos, desde o tsunami que assolou a costa asiática em dezembro de 2004, até o recente desastre decorrente das chuvas no Rio de Janeiro, com a importância e necessidade de conservar os recursos e os ciclos evolutivos dos ecossistemas. Embora tivéssemos um passado rural, onde a maioria da população brasileira morava no campo, hoje ele já não existe e muito mais foi perdido, além do solo e de várias espécies. Com isso, percebe-se certa distância e até desconfiança quando alertamos que muitos dos recursos naturais devem ser manejados racionalmente para que o processo de renovabilidade seja viável, caso contrário ele se esgotará.

O impacto das catástrofes, naturais ou não, seria menor se a interferência do homem sobre o ambiente fosse mais bem planejada e adequadamente monitorada (Ferreira 2008). É lamentável constatar que o Brasil é um dos campeões na contribuição para aumentar os impactos das mudanças climáticas e isso se deve, principalmente, ao desmatamento, às queimadas e às alterações no uso do solo. Portanto, evitar a destruição da natureza é uma contribuição fundamental para a conservação da biodiversidade brasileira e para a amenização dos efeitos das mudanças climáticas.

O modelo de desenvolvimento adotado pelo Brasil, com visão no curto prazo, contribuiu neste processo e infelizmente criou uma cultura imediatista, onde os problemas ambientais parecem distante da realidade das pessoas e por vezes, incompreensível. Porém, não resta dúvida de que existem alternativas e um caminho a percorrer. Há que se trabalhar pelo fortalecimento das instituições e pela consolidação de parcerias para que sejamos capazes de garantir recursos financeiros e humanos para alcançar a missão de conservar a natureza para a coletividade.

\section{Referências}

Djoghlaf A, 2010. [cited 2010 March 15]. Avaliable from: http://www.cbd.int/.

Fernandes RC, 1994. Privado porém público: o terceiro setor na América Latina. 2 ed. Rio de Janeiro: Relume - Dumaré.

Ferreira CC, 2008. A atuação do terceiro setor na defesa do meio ambiente: aspectos Legais. [cited 2008 March 24]. Available fom: http://www.ambitojuridico.com.br/.

Gonçalves HS, 2002. O estado o terceiro setor e o mercado: uma tríade completa. [cited 2008 November 20]. Available from: http://www.rits.org.br/.

A falta que a informação nos faz, 2010. JB Ecológico, (Belo Horizonte).

Landim L, 1993. Para além do mercado e do estado? Filantropia e cidadania no Brasil. Rio de Janeiro: ISER.

Rothgiesser TL, 2002. Sociedade civil brasileira e o terceiro setor. [2008 October 20]. Available from: http://www. terceirosetor.org.br/.

Recebido: Abril 2010

Primeira Decisão: Abril 2010

Aceito: Abril 2010 